\title{
Second Coming, Successful Life and the Sweetness of Guinea: Evangelical Thoughts about the Future in Guinea-Bissau
}

\begin{abstract}
Hope, aspirations and drives to the future are the focus of a recent academic concern about the multiple ways in which people are thinking and producing their future in a time of great uncertainty. By exploring the peculiar ways in which Evangelical believers in Guinea-Bissau are engaged in thinking their future, this article aims to portrait Evangelical Christianity as a source of hopes, aspirations and visions of possible futures in contemporary Africa.

Moreover, by comparing the program of cultural and social regeneration pursued by nationalists in the 1960s-70s, and the current Evangelical project of personal and collective redemption, I argue that Evangelical churches are promoting today a politics of hope that translates Amílcar Cabral's legacy in their own terms. Finally, I show how, in front of the failure of nationalist narratives, Evangelical churches are fostering an emerging conceptualization of modernity as connectivity, underlying new dreams of a better future.
\end{abstract}

Keywords: future; hope; aspirations; Guinea-Bissau; Evangelical Christianity; modernity

\section{Introduction}

I arrived in Bissau on 31 December 2012. On 12 April, a coup d'état - the third in the post-colonial history of Guinea-Bissau - had overturned the democratically elected government, installing a provisional administration. I spent New Year's Eve in a congregation of the Ministério de Amor pela Fé Internacional, a national Pentecostal denomination. The New Year worship began in the dark - as usual there was no electricity at night. Down the hall, a plexiglass pulpit was lit by a weak bulb, creating quite a charming effect. For the special occasion, the choir was led by a young singer who is well known in Guinean Evangelical ${ }^{1}$ circles. The concert started unplugged. Then, almost miraculously, the light appeared, and someone ran to crank up the amplifiers. After a long alternation between music and testimonies, finally the pastor reached the pulpit and took the floor. His message focused on the subject of time. 'Whereas God is out of time', he said, 'We are controlled by time. But this is also a time that God gave us to be blessed and used by Him, a time that does not belong to us. This year, 2013, is a time that God has given us to be blessed, to be used by Him'.

At the very beginning of 2013, time was one of the most recurrent issues in sermons and everyday conversations, together with the closely related topic of vision (vison in Kriol). I will return to this subject later. For the moment, it is sufficient to note that vison has to do with individual and collective aspirations, with dreams of a better life, with hopes and drives to the 
future. All of these issues are the focus of a recent academic concern about the multiple and varying ways in which people are struggling to imagine and produce their future in a time of great uncertainty (Crapanzano 2003; Weiss 2004b; Miyazaki 2005; Miyazaki 2006; Guyer 2007; Cole 2010; Piot 2010; Moore 2011; Appadurai 2013).

By exploring the peculiar ways in which Evangelical believers in Guinea-Bissau are engaged in imagining, thinking and producing their future, this article aims to show how religious faith, and namely African Evangelical Christianity, may constitute a way of giving shape to hopes, aspirations and visions of possible futures by channelling them into a specific moral discourse. In discussing these issues, I follow those scholars who described Evangelical and Pentecostal churches as central agents of optimism, hope and vitality in contemporary Africa, insofar as they promote a new orientation toward time that leave the past behind, focusing on self-transformation and active waiting of the world to come (Cole 2010; Piot 2010). Firstly, I will describe the specific and multiple visions of time circulating among Guinean Evangelical believers, associating them to particular historical circumstances, on the one hand, and peculiar ideas about future and hope whose origin can be traced back to Christian traditions, on the other. Secondly, I will compare the program of cultural and social regeneration promoted by Amílcar Cabral and the PAIGC ${ }^{2}$ in the 1960s-70s, and the project of personal and collective redemption currently pursued by Evangelical churches in Guinea-Bissau, highlighting similarities and differences. On this basis, I will argue that, in contemporary Guinea-Bissau, Evangelical churches are promoting a new politics of hope that translates Cabral's legacy in their own terms. Finally, I will show how, in front of the failure of the nationalist narrative of modernization in contemporary Guinea-Bissau, Evangelical Guinean churches are fostering an emerging conceptualization of modernity as connectivity, which underlies new dreams of a better future.

This article builds upon ethnographic research realized in Bissau at the beginning of 2013. The starting purpose of my fieldwork in the Guinean capital was to reconstruct a genealogy of the Evangelical movement in Guinea-Bissau through oral history. Nonetheless, while I was inquiring into the past of the local Evangelical community through the memories of Christian leaders, I became aware of the crucial importance of future in the discourses of most believers. The data which form the basis of this article consist of twenty-two recorded in-depth interviews with pastors, missionaries and leaders, as well as seven recorded sermons, collected during the religious services I attended in town ${ }^{3}$. In addition, since I was a guest of an Evangelical family, I had the opportunity to participate in their daily life, and to entertain several informal conversations with my guests and their kin and neighbours, both believers and non-believers. 


\section{Future, hope and aspirations}

Since the 1990s, the end of the Cold War, the global spread of neoliberal policies and the emergence of the so-called 'globalization' coincided with the demise of the great twentieth-century narratives about the world to come, as well as with and the emergence of new desires and expectations. In this time of rapid change, enhanced connections, acute inequities and large-scale human movements, recent contributions in social and cultural theory have witnessed a tension between the spreading of insecurity and radical uncertainty in contemporary world, on the one hand, and the emergence of multiple forms of future-making and future-thinking, on the other. More generally, many scholars have been concerned with the rise of new hopes, aspirations and imaginations of possible futures in today's world, suggesting the emergence of a new paradigm (Crapanzano 2003; Weiss 2004b; Miyazaki 2005; Miyazaki 2006; Guyer 2007; Cole 2010; Piot 2010; Moore 2011; Appadurai 2013).

In anthropology, several important contributions have recently advocated a shift from an enduring concern with persistence, stability, and fixity, to a focus on potentiality, transformation and anticipation in social life (Moore 2011; Appadurai 2013). These authors have stressed how, as far as the discipline has been preoccupied with the logics of reproduction, memory and tradition, it has largely neglected the many ways in which human groups have shaped and anticipated the future, leaving the task of a systematic analysis of future-making to other disciplines, such as economics, environmental sciences, design, architecture and planning (Appadurai 2013). However, as pointed out by Henrietta Moore, 'we may be haunted by our pasts, but human social life is equally lived in a relentless forward gear' (Moore 2011:1). That is why, 'instead of reading culture backwards, looking at it in the past tense', Moore proposed to 'examine how it is deployed as a means for dealing with the alterity of the future, with the not-yet' (Moore 2011:13). Furthermore, by focusing on hopes, desires and satisfactions as human possibilities, she emphasized 'the radical potentialities of human agency and human subjectivity, their essential openness [...] to new ways of being' (Moore 2011:22).

In a similar vein, Arjun Appadurai (2013) presented a manifesto for an anthropology of the future, suggesting to examine the future as a cultural construction that takes variable forms, according to historical circumstances. Among the human preoccupations that shape 'the future as a cultural fact', Appadurai payed special attention to the 'capacity to aspire', understood as a social and collective capacity, which though universally distributed takes shape in many different ways, manifesting itself in local systems of value, meaning and dissent. Central to the idea of aspiration are the various ways in which different groups of people, relative to their society, produce particular ideas of 'good life', that is, what people hope to achieve under the circumstances of having an 
unsatisfactory present. In his view, examining cultures through the logic of reproduction supports the idea that social groups are generally satisfied with the state of affairs in which they find themselves. Conversely, a broader understanding of cultural systems should also take into consideration the 'politics of hope' through which any society or group can imagine a change in their lives (Appadurai 2013:293).

Basing their analysis on the African continent, Brad Weiss and others (Weiss 2004b) explored the ways in which the future is produced in radically uncertain settings. As pointed out by Weiss, in the latter half of the twentieth century the implementation of neo-liberal reforms in African countries has led to unprecedented changes and historically specific formations. Indeed, a number of factors connected to neo-global processes - including the declining sovereignty of governments, the contraction of the public sector, the flourishing of unregulated markets and the polarization of wealth and poverty, with its corollary of crime outbreaks, armed conflicts and anxieties about 'occult economies' (Comaroff and Comaroff 1999) - have contributed to the emergence of an expanding sense of crisis in contemporary Africa (Weiss 2004a). In Weiss's view, what characterises this new age is a radicalization of the contrast between inclusion and exclusion in the global world. On the one hand, thanks to a growing circulation of commodities and images, Africans are engaged more than ever in multiple modes of connection, identification and affiliation on a global scale, such as the participation in international religious networks and in long-distance migration chains. On the other hand, as opportunities to participate in the global flow of capital are confined to small elites, for most people the rising possibilities of global connection coexist with a growing sense of marginality. Hence, as people seem less and less able to envisage their immediate future, for the majority of the African population late capitalism has been a time of radical insecurity and uncertainty about the future.

And yet, as observed by Jean and John Comaroff (2004), despite being a time of dramatic transformation, extreme privation and institutional collapse, in Africa the post-Cold War era is also a moment of great creativity in the fields of informal economy, new imaginaries and religious movements. Facing this enforced present, people appear to react in two different ways: while some show a growing sense of despair, other respond with an intensification of desire and the will to aspire. As a matter of fact, efforts to achieve well-being in the face of scarcity and insecurity are constantly planned and enacted. Examples include the engagement in informal economies, the use of force as a mode of redistribution, as well as the Pentecostal prosperity gospel ${ }^{4}$. Hence, as stressed by the authors, 'Afropessimism' and despair can go hand in hand with hope (Comaroff and Comaroff 2004:346). 
Focusing on the Togolese case, Charles Piot (2010) used the expression 'nostalgia for the future' to evoke people's longing for a different future that is expected to replace an awkward and haunting past. In his view, by reiterating Christian narratives of re-birth and End of Time, by embracing non-governmental development projects that favour youth rather than elders, and by engaging extensively in migration plans, Togolese are expressing their exhaustion with the older Cold-war narratives that either connected West Africa to the metropole or celebrated local traditions. In other words, by participating in these initiatives people are conveying their desire for a new beginning, faced with the failure of colonial and post-colonial ideologies. Especially, as pointed out by the author, the spreading of Pentecostal stories of personal and cultural forgetting can be read as an attempt 'to redefine historical agency—as less about a relationship to or debt with the past, or to a colonial/postcolonial other in the present, and more about a nostalgia for the future' (Piot 2010: 67).

By describing the specific ways in which Evangelical Guinean believers are engaged in thinking and producing their future, in this article I will portrait the Evangelical Guinean world as a crucial site of future-making and future-thinking in contemporary Guinea-Bissau. My analysis follows up on Piot's understanding of Christian churches as agents of transformation, hope and vitality in present-day West Africa. However, my interpretation of the Guinean case will mitigate his insistence on rupture, bringing to light the elements of continuity with the past. In the following pages I will show how, while promoting a new orientation toward time that anticipates the future and leaves the past behind, Guinean Evangelical narratives are simultaneously connecting with the recent collective past in order to imagine a common future. Namely, by analyzing the references to Amílcal Cabral and liberation war in Evangelical discourses, I will argue that these churches are presenting themselves as the very heirs of Cabral in contemporary Guinea-Bissau, insofar as they are revitalizing, after their own fashion, the utopian impulse of those who fought for independence.

\section{Dreaming of a better life in Bissau}

One day at the beginning of 2013 I visited Casa Emmanuel, a multifunctional centre located in the outskirts of Bissau. The centre, founded by a Costa Rican Pentecostal missionary and financed by Portuguese Cooperation, includes a small hospital, an educational institution running from nursery to high school and an orphanage. According to many people, Casa Emmanuel is one of the few sites offering adequate social services in Bissau. Isabel Johanine, the founder and current director, told me that God gave her the vision and the means to build what she calls a projecto modelo (an 'exemplary project'): 
Our model is one of comprehensive implementation of childcare. It is like a small country that has all the necessary policies. What is needed to practice good childcare? You need health, education, a social area, waste collection, potable water and electricity [...].

Guinea-Bissau is like a child who has a little, but who lacks everything; a child that is crying, who would like to have a different life. I love this country, it may have many faults, but I love it. And this is how I see it: as a child calling for something better for her. The parents of this child, to wit the government, do not respond to all of the child's needs. They are parents who do not care about their daughter, who are selfish and just think about themselves, who should help more. That is how I see Guinea-Bissau ${ }^{5}$.

While I was talking with the director, the First Lady appeared to visit the centre, accompanied by a television crew. Waiting to continue the interview, I took a tour in the courtyard of the orphanage. On the wall of a small building, I saw a man painting a mural, representing a lush island with a hut at the mouth of a river. Next to it was another painting, with a sunrise framed by two palm trees and a sentence saying: 'Para que o teu filho viva amanha, num mundo dos teus sonhos. Amilcar Cabral' (So that your son may live happily tomorrow, in the world of your dreams. Amílcar Cabral). At first, I felt puzzled by this scene. The words of a Marxist revolutionary seemed to me quite out of place, painted on the wall of an institution established by a Pentecostal missionary. And yet, later on, I realized that this episode summarizes many of the elements I bumped into, as I was exploring the specific temporality experienced by Evangelical Guineans: a South American Christian missionary, an African version of the island of Utopia, a social institution managed by a religious NGO and financed by international cooperation, the shadow of a murdered national hero, and the dream of a better future.

Guinea-Bissau is a small Western African country situated on the Upper-Guinean coast, bordered by Senegal to the north and east, and Guinea-Conakry to the east and south. Despite the small dimension of its population, which is of about one and a half million inhabitants, the country is characterized by a great ethnic plurality, resulting from a series of migration flows and longdistance trade routes that have crossed its territory over the centuries (Rodney 1970; Brooks 1993; Brooks 2003; Knörr and Trajano Filho 2010). The Portuguese presence in this territory dates back to the fifteenth century, when Portuguese and Cape Verdean navigators contributed in creating coastal centres dedicated to slave trade and commerce with local groups. In those fortified villages emerged the Kriol, a lingua franca aimed at facilitating communication between people speaking mutually unintelligible languages. People of mixed ancestry born in these Portuguese strongholds gave rise to the Guinean Creole society, who played a central role both in colonial times and in the post-independence (Trajano Filho 1993; Trajano Filho 2010). 
Among the former Portuguese African colonies, Guinea-Bissau has the oldest history of anti-colonial resistance, culminated in one of the longest and bloodiest colonial wars in the history of Portuguese empire, lasting from 1963 to 1974. Its independence was unilaterally proclaimed in September 1973, being recognised by Portugal one year later. Since then, the country has collected three coups (in 1980, 2003 and 2012), a civil war (1998-99), plus several unsuccessful attempts to seize power by force, regularly followed by political murders and human rights violations. As observed by Henrik Vigh, persistent political unrest, institutional collapse and economic decline in post-colonial Guinea-Bissau have led to a situation that could be described as a state of 'enduring instability' (Vigh 2010:154).

Like in other African countries, the post-Cold War moment constitutes an historical turning point in Guinea-Bissau. The gradual loss of support from the Soviet bloc urged President Nino Vieira, who came to power in 1981 through a military coup, to request a financial 'rescue' to IMF and WB. In exchange for aid, a structural adjustment plan was requested and eventually launched in 1986. The following process of political and economic liberalization entailed a set of economic measures and constitutional adjustments, including cuts in public spending, privatization of state companies, as well as the establishment of a multiparty system. As in many other cases, these reforms did not produce the expected results, generating instead the devaluation of the national currency; a sharp rise in inflation, external debt, unemployment and costs of living; a further polarization of wealth and poverty and an increase in political instability. Furthermore, since 2000 the country has gradually become a transit point for narcotics smuggled from South America to Europe, with large sections of the army and political class being involved in transnational trafficking. As a result, international media started to refer to the Republic of Guinea-Bissau as a 'narco-state' (Duarte Silva 2010). As in other West African countries, the implementation of neoliberal policies in a context of widespread corruption has produced a process of to 'criminalization of the State' (Bayart et al. 1999), marked by the alliance between patrimonial and criminal networks.

These events led to a rapid impoverishment of the population, particularly acute in the case of middle and urban classes. People were progressively deprived not only of their means of social reproduction, but also of the main services expected in the urban life, such as electricity, water supplies, school, public health and other public facilities. In this context, the contrast between the increasing availability of foreign images and goods and the lack of opportunities to appropriate them is experienced by most Guineans as a growing gap between desire and possibility (Weiss 2004a; Bordonaro 2009). Young urban males are especially affected by this situation, as lack of resources and employment force them to remain dependent on family elders, without the possibility 
of getting married and achieving adulthood, and being stuck in a state of 'social moratorium' (Vigh 2010:148). Among the younger generations, thus, the apparent impossibility of securing a future at home, on the one hand, and the aspiration to a 'modern life', understood as a set of institutional and economic conditions of life (Ferguson 2006), on the other hand, has resulted in a generalized 'quest for exile' (Piot 2010). Indeed, transnational migration appears today as one of the few opportunities to claim citizenship in the global world, a claim which is expressed, in Kriol, in the recurring phrase 'sai fora', 'get out' (Bordonaro 2009). However, as the vast majority of people are excluded from migratory networks, desires of escape remain largely unfulfilled. This social and physical immobility engenders a rising sense of exclusion, frustration and marginalization.

As noted by Wilson Trajano Filho (2008), the inhabitants of Bissau distinguish, as the key time marker of this period, the '7 June War' (1998-1999), a military uprising that quickly became a civil war ${ }^{6}$. Mostly concentrated in the capital, which was also invaded and plundered by foreign troops, the war ended with the removal of Nino Vieira. Collective memory recalls this moment as when things got out of control and people were no longer able to imagine and foresee their actions and those of others, with radical consequences for social life. In people's minds, the event is depicted as a long fight between brothers and across generations. Indeed, many families split up, with younger boys recruited within the militias supporting Nino Vieira, and older men fighting for the Junta Militar (Trajano Filho 2008; Vigh 2010). According to common understanding, the civil war led to a time of deep uncertainty, state collapse, and violent conflicts between self-seeking politicians. The acute sense of insecurity and absence of social norms is evident in the rumours that, as noted by Wilson Trajano Filho (2008), constitute a collective way of commenting on political and social facts, especially within the Creole society living in Bissau. Among the favourite topics of these stories, full of gruesome details, are the wrongdoings of powerful and notable people. One of the most famous rumours depicts the former president Nino Vieira in the act of eating raw human flesh; another describes the repugnant behaviour of President Kumba Yala and his bodyguards, who were said to urinate and defecate in the corridors of the presidential building. These rumours share the tendency to represent the actions of the powerful in terms of excess, appetite, occult powers, and 'state of exception' (Agamben 1998; Piot 2010), giving the idea that members of the elite live in a dimension of transgression in which laws and rules of common life are suspended.

Besides being reflected in Creole rumours, this sense of decline and social deterioration is also evident in the ways in which everyday life is commonly experienced and understood. As pointed out by Trajano Filho (2008), the current organization of time in Bissau follows neither the course established during the colonial period - when time for labour and time for rest were clearly distinguished - nor the seasonal and cyclical rhythm of the pre-colonial periods. Rather, the specific 
temporality of everyday life in Bissau seems marked by improvisation and dissolution of the daily routine. As most people do not have a regular source of income, nor can they rely on family networks or the state to meet their most basic needs, they have to improvise, using all their skills and expertise to secure their daily survival. Describing the everyday life of young people in Bissau, Heinrich Vigh (2010) observes an attitude towards the present that he associates with the emic notion of dubria. This verb - probably deriving from the French se débrouiller, meaning to get by or make the most of a situation - refers to the act of overcoming the difficulties of everyday life through creativity and smartness. It is a form of 'navigating' the unfolding terrain of social relationships in contemporary Guinea-Bissau:

\begin{abstract}
Dubriagem designates the act of making the most of a situation and making things work to one's advantage. It is [...] a dynamic quality of attentiveness and ability to act in relation to the movement of the social terrain one's life is set in. Thus dubria, the active form of the verb, encompasses both the immediate assessment of the dangers and possibilities of one's present position as well as the ability to envision, plot and actualise an advantageous movement from the present into an imagined future. In other words, it encompasses, both immediate survival and the drawing of trajectories into the imagined future [...], designating a temporally dense action complex enabling one to survive in the here and now as well as to see one's life; i.e. to gain an idea of the possible course of one's life trajectory in an unfolding social terrain. Dubriagem, as such, refers to both the praxis of navigating a road through shifting or opaque socio-political circumstances and the process of plotting it (Vigh 2010:150).
\end{abstract}

Despite its common usage amongst all social groups, the term has a special meaning for youth, 'dubiaduris par excellence' (Trajano Filho 2008), being often associated with the will to escape. As observed by Trajano Filho, if dubria is a form of surviving in an unstable setting, young people in Bissau 'only remain alive in order to fulfil radically what they believe is their fate and hope: to exit the system, to emigrate to Europe in search of fulfilment of their social becoming' (Trajano Filho 2008:251).

In this sense, as well as a form of praxis or strategic action, dubria is a judgment on a social system which is perceived as inexorably collapsing, a sinking ship from which everybody would like to run away. To the extent that many young Guineans live in the constant expectation of an opportunity to leave the country, their aspirations being all invested in a flight from a stagnant present, their attitude seems to reflect a pessimistic point of view, in which the country is seen as suspended in a hopeless present, in a dimension of durable decline. As observed by Trajano-Filho (2008), such gloomy vision has to do with the disrepute into which the previous social narratives fell, those that placed actions and aspirations in a more general framework, including the colonial rhetoric of 'civilization', the libertarian narrative of African nationalism and the neo-liberal ideology of society governed by the market. Indeed, in this post-Cold War moment the failure of the promises of these narratives has resulted in widespread frustration and disillusion. In urban GuineaBissau, rumours and dubria attitudes seem to reflect a pervasive sense of disintegration in all areas 
of life; to use the words of Chinua Achebe, a sense of 'things falling apart'. Apparently, the aspirations of many Guineans have gradually been channelled towards a private and personal horizon, focusing on the single individual and his/her close family, at the expense of collective dreams of a better life.

However, as it was observed, the crisis in contemporary Africa does not only lead to pessimism. On the contrary, signs of vitality are visible in the many ways Africans are responding to the crisis, by seeking to secure and envision their future, despite living under radically uncertain conditions (Comaroff and Comaroff 2004). From my particular point of view, I believe that in urban Guinea-Bissau, one of the sites in which this liveliness is more evident is the Evangelical world. This is evident in the ways Guinean Evangelicals are becoming increasingly active in the country's social life, as well as in the complex forms in which they are engaged in planning and imagining a better future, not only at an individual level, but also more generally.

Until recent times, Evangelical Christianity was a minority religion in Guinea-Bissau, a country where the majority of the population prevalently practiced Islam, local religions and, to a lesser extent, Catholicism. However, Evangelical churches have experienced a strong increase in the last two decades. The first Protestant missionaries arrived in Portuguese Guinea in the early 1940s, and were authorized by the Portuguese administration to conduct missionary activities under the name of Missão Evangélica (ME) ${ }^{7}$. In 1970, the latter founded the first Protestant denomination in the country, the 'Igreja Evangélica da Província da Guiné', later renamed 'Igreja Evangélica da Guiné-Bissau' (IEGB). Initially, the Evangelical community was very slow growing, being primarily formed by creolized urban groups living in the Bissau region. Indeed, it was only since the 1990s that mission activity began to get substantial results. This shift was highly influenced by the process of economic and political liberalization which started in the last 1980s. As a matter of fact, the new version of the constitution regulated more clearly than before the relationship between secular state and religious institutions, sanctioning the freedom of worship, the right to teach any religion, and the protection of legally recognized confessions. One of the effects of this change was the multiplication of worship places and Evangelical denominations, both of national and foreign origin $^{8}$. While until that moment the ME was the only Protestant organization recognized by the authorities, from now on new churches were allowed to establish congregations in the country. As a matter of fact, in the 1990s a large number of denominations coming from Brazil, and to a lesser extent from the United States, Nigeria and Ghana, began to set up and carry on mission activity in Guinea-Bissau. In line with the separatist nature of Protestant Christianity, this rapid growth resulted in the internal differentiation of the movement, which now includes both conservative currents and churches of Pentecostal and neo-Pentecostal inspiration. 
The main turning point in Protestant history was probably the civil war of 1998-99, due to the central role played by Evangelical churches in the process of conflict mediation, as well as in humanitarian initiatives directed to civilians. In this sense it is remarkable that, while the inhabitants of Bissau commonly consider the civil war as the key event that marked the shift towards the current crisis, Evangelical believers understand this conflict as the beginning of a new era, in which churches have gained growing visibility in and influence over Guinean public life. Today, despite its internal divisions, the Evangelical minority is gaining an increasingly central position in Guinean society, both in religious sphere and in public life.

\section{Multiple temporalities between Bissau and the Kingdom of God}

Within the recent literature about future, hope and aspirations, some scholars have paid attention to what they consider to be the distinctive features of the dominant temporality at the beginning of the twenty first century. According to Arjun Appadurai, the emerging diacritic of this age of late capitalism is 'the domination of techniques and mentalities oriented to manipulating or withstanding risk' (Appadurai 2013:3). These risk-based orientations and practices include many different phenomena, ranging from financial speculation to various forms of gambling, forecasting and vernacular understanding of uncertainty. In his view, what is currently emerging is a tension between the 'ethics of possibility' and the 'ethics of probability', that is, between the managerial ethos arising from the statistical representation of risk, on the one hand, and the multiple ways of thinking, feeling, and acting which encourage the work of hope, imagination and aspiration, on the other.

Jane Guyer (2007) has recently discussed how, in the current post-Cold War period, the public culture of temporality in the United States is marked by a concentration on the extreme longterm, a fixation on the immediate present and an evacuation of the 'near future', understood as a field of active engagement in the social world. In her view, this disconnection between the short term and the long run is evident in neoliberal fantasies about the self-regulation of markets, which at some unknown point in the future will overcome instabilities and deliver enduring growth, as well as in Evangelical faith, which projects human longings for a better world in the belief in the Second Coming of the Messiah. Furthermore, the author observed how the current perception of time is punctuated rather than continual, in contrast with the idea of a homogeneous time which has persisted from the beginnings of Western modernity to the post-war era. It is a 'prophetic time' which is composed no longer of a sequence of dates, but of a collection of events, fateful moments, epiphanies and life-changing turning points. As Guyer recognized, these rhetorics and exhortations 
resulted in dominant forms of temporality, whose global circulation 'give the impression of us all living in the same world at the same time' (Guyer 2007:418). And yet, we are not all necessarily living in the same dimension. On the contrary, alternative perceptions of time are unceasingly emerging in particular corners of the world, coexisting with and reinterpreting hegemonic configurations.

In this paragraph, I will focus on the visions of time circulating among Evangelical believers in Guinea-Bissau. In such context, I argue, specific ideas about time emerged from the encounter between particular historical and cultural circumstances, on the one hand, and peculiar ideas about future and hope that have their origin in Christian traditions, on the other. The outcome of such cross-over, I believe, should not be understood as a coherent synthesis generated by a process of hybridising or syncretism. Following Jennifer Cole (2010), I rather see this intersection in terms of a synergy, wherein local views merge with Christian categories of time. An additional variable to consider is the coexistence, within the heterogeneous Evangelical Guinean world, of multiple Christian traditions, including old and new denominations, national and foreign churches, as well as conservative, Pentecostal and neo-Pentecostal patterns. Hence, rather than a cohesive perspective, this emerging vision of time is better represented as a set of 'multiple temporalities' (Cole 2010) used by individuals according to variable circumstances and different communicative contexts.

As a backdrop to these multiple temporalities is the Christian notion of hope. As observed by many authors (Entralgo 1957; Bloch 1986; Crapanzano 2003), hope is part of the very essence of Christian religion. Waiting to reach the Kingdom of God is a crucial theme in Christ's teachings and throughout the New Testament, and hope was included among the three theological virtues in scholastic theology, alongside faith and charity. What distinguishes the Christian interpretation of theological hope is its transcendent origin, as Christian hope is a virtue infused by God in men's heart (Entralgo 1957). Concurrently, even within Christianity the notion of hope has been subjected to multiple interpretations according to distinct traditions and different historical contexts. For instance, liberation theology's hope in actual social change is quite different from the hope in personal success promoted by prosperity theologians.

Besides the Christian category of hope, a second assumption underlying the multifaceted vision of time circulating within the Guinean Evangelical world is that Christians must 'make a complete break with the past' (Meyer 1998). As many authors have pointed out, Evangelical and Pentecostal discourses in Africa conceive personal and collective past - weather associated with a personal life of sin, or with traditional ways of life - as a looming threat on the present. Conversely, to the extent that the jettisoning of tradition can 'anticipate the future while closing its eyes to the past' (Piot 2010:164), the promotion of a rupture with the past goes along with a symmetrical 
projection into the future. Yet, while Evangelical Guineans share this drive towards the future, this intention can be experienced and expressed in multiple ways.

Among Evangelical Guineans, I suggest, the idea of future is shifting between three different temporalities. The first horizon is directed to the distant future, being associated with the End of Time narrative. The second and the third perspectives, both contained within the notion of vison, are oriented towards the near future.

\section{Waiting for the End of Time}

As anthropologists of Evangelical Christianity have highlighted (Crapanzano 2001; Harding 2001; Robbins 2004), since the 1970s most branches of Protestantism, in the Unites States and all over the world, have embraced a radically millennialist orientation toward time, focused on waiting for the Second Coming of Jesus Christ and the subsequent End of Time. According to this widespread narrative - based on the Book of Revelation, the Book of Daniel and the Letters of Paul - the current age constitutes a pause between the first and second coming of the Messiah. In John's prophecy, when Christ returns, the righteous will be separated from the wicked, with true Christians ascending to heaven, and sinners being condemned to a world of war and suffering governed by the Antichrist. Then, time will turn into eternity. Believing that time is about to end, most Evangelicals all over the world experience daily life with an attitude of 'expectant waiting' (Guyer 2007), constantly reading the signs of the Parousia, which is simultaneously deemed both imminent and undetermined. Understood as a gap in time endured by waiting and witnessing, as in the Letters of Paul, the 'time of now' is lived as a 'messianic time', a 'time that remains', an 'unfinished pause' (Agamben 2005:64) or a 'future unfolding' (Harding 2001:240). It is also a time marked by a paradox: while salvation is already accomplished for believers, its complete fulfilment requires yet more time, since the End of Time is still to come (Agamben 2005).

Besides conditioning congregants into a millennialist orientation towards the future, this narrative provides a frame for interpreting present life, such as global or local events - wars, floods, earthquakes, etc - which are constantly scrutinized in the search for signs of the Second Coming. Of course, financial bankruptcies are also understood within this framework, including the global economic crisis started in 2007, as in the words of Pastor Quintino, a senior minister living between Bissau and Lisbon:

Well, of course, it may be early, it cannot be too soon, but someday He will return. Because the signs foretold, when Christ was living, they have already been seen; for example, earthquakes, floods, wars [...] and the return of the Israelites to Israel [...]. It's all in the Bible, prophesied by Jesus. And this crisis, think only about 
this crisis that is occurring here [in Portugal]. The European Union, when did it start? It has been prophesied in the Bible [...]. In the book of Daniel, chapter 7, you see? Have you heard of Freemasonry? [...]. And what is behind this secret organization? It's the devil! All the powers are concentrated in them, economic power as well. They are concentrated in them, aren't they? It is clearly prophesied in the Bible, anyone who reads understands that the End is near.

Despite the centrality of the End of Time narrative found in the speeches of pastors and leaders, waiting for the Second Coming does not seem to have a deep influence on the everyday life of Evangelical believers in Guinea-Bissau. Apparently, simple churchgoers are interested less in the remote future horizon, and more in the short and middle term.

\section{Vison di nha vida (vision of my life)}

The second orientation is focused on the individual, and is based on the concept of vison (vision), a recurring subject in New Year's sermons. It was the case of the message given by Pastor Silvério Quiletch, a young and recently ordained minister, leading a congregation located in a north-western suburb of Bissau:

None of us should be side-tracked by the things of this world that lead us to do evil, and that distract us from our vison [...]. Every single person who is here has a vison, which is different from that of others. This is to say that we should be prepared, we should be vigilant about always being righteous, not to get swayed, not to walk to the right or the left, but to keep on the straight and narrow [...]. We are at the threshold of a new year, going forward to continue fighting, striving to achieve our vison. But a question must be asked: What is your vison? I want to be the best, but to be the best depends on God, on what God wants for you. I want to be the most exemplary student in my class, or in the entire school. You can. If you want to be a great football player like Messi or Cristiano Ronaldo, you can. In your job, you aim to be a good employee, so that your boss will like you. Or you want to be a politician, the best politician in Guinea, or wherever it may be in the world, it is also possible. In your marriage, everyone praising you, this can also be what you aim for. And also in your love story, what is your vison? Because there is always a vison; because God or Jesus have a great vison, but what we humans lack, is to be prepared [...]. We have to keep track of our vison [...].

This year, 2013, you have to be alert. I'll be a true believer; I'll be a believer who will do great things [...]. The devil tried to distract Jesus Christ in a number of ways, but Jesus had his vision, he died on the cross for our sins. You are at the beginning of 2013, now the devil will try to distract you, but you will win. You will win in the name of Jesus. You have your vison. From now on, you will win [...]. It has to be clear that you are children of God, and you do not accept distractions.

As Pastor Quiletch told me after the service, 'Vison cannot be seen by the naked eye, it's about what you want to achieve in your life. I want these people here to know the truth of Jesus Christ, so that 
they do something for this church and especially for this nation'. First of all, as the pastor stressed in his sermon, every single person has a plan for his or her life, everyone has a special dream: one person wants to excel in his or her studies, another wants to have good conjugal relations, another wants to be a great politician or football player, and so on. What distinguishes Christians from the djinti di mundu (people of the world) is that they know that God has a special plan for them.

The notion of vison has its origin in a basic principle of Christian theology, which places salvation and truth within the individual believer, as the main site of the encounter with God. And yet, as was taught by Augustine, it is not by his/her own virtue that a Christian can find the transcendental within him/herself, but through the grace of God. Therefore, from a doctrinal viewpoint, the Evangelical idea of vison has a double dimension: on the one hand, it is the plan that a single believer has for his/her life; on the other, it is the plan that God has for his/her individual salvation. Thus, the precondition so that each believer can fulfil his/her plan is that the inner vison matches God's vison.

But how to know if the personal views are in accordance with the will of God? The understanding of God's design for one's life is a matter of both divine inspiration and discernment capacity. In fact, one can never be certain that one's vison corresponds to that of God, as proved by the common narratives that pastors share about their calling to ministry. A recurrent trope is that before becoming a minister the individual in question had plans of personal achievement - be these professional or academic - that had nothing to do with pastoral vocation. However, at a certain point in his life, God called him to dedicate his life to His service, through dreams, prophecies, and Bible readings. Like in the stories of biblical prophets, the eventual pastor first tried to resist God's call, but then, after a series of personal failures, he came to accept God's design and surrender to His will. This was the case of Pastor Eliseu Gomes, a Guinean ministry who is actually leading an African congregation in Lisbon:

My vocation occurred when this missionary team, YWAM, arrived [in Guinea-Bissau] [...]. One day I sat under a tree to read the passage that they told us to meditate; it was Joshua chapter 1 . The word that stroked me very strongly was when God was speaking to Joshua, that no one can resist all the time of his life. And God said: 'As I did with Moses, so will it be with you'. And that word, I started... it was as if God was talking to me, not with Joshua. How many times I tried to swerve, I did not want to work a lifetime for God? I wanted to walk around, doing my work, [I thought that] my life could serve God also otherwise. But God did not want that, He wanted me to give myself totally [...]. I even swerved, I did a professional training, but the training was not doing well. Everything I was doing was not working [...]. When I went to YWAM, there it was that things began to change. 
These testimonies confirm Moore's point that, as preachers and believers remodel the narratives of their lives on those of biblical figures, sacred texts provide a sense of revealed truth, life transformation and sense of possibility. By connecting their personal experiences to broader Christian narratives and ultimate truths, these 'forms of self-fashioning' are particularly powerful 'because they link the desires of self-realization to forms of legitimacy and authority that transcend context' (Moore 2011:62).

Hence, Evangelical narratives identify divine inspiration as a primary source of orientation in personal life plans. At the same time, in order to align with godly designs, believers are expected to maintain a constant and intimate relation with God through various techniques of the self, such as fasting, prayer and Bible reading. Frequently, the recurrence of specific biblical verses in particular moments of one's life is held as a communication channel with God, as evidenced in Eliseu's story. Only when a believer makes his/her heart, mind and senses open to the word of God, only then s/he will be able to understand the will of God. A second condition for the discernment of God's plans is thus self-discipline: as Quiletch stressed, believers have to remain focused on their vison, without succumbing to the distractions sent by Satan. Although the correspondence between personal and godly visions can never be taken for granted, worshippers can obtain a certain level of security if things are going according to their plans - if they are succeeding in their studies, their relationships, or their profession. Vison is something that requires attention and care, which must be cultivated, disciplined and protected. If the plan of a believer is in accordance with God's design, and s/he continues on the righteous path, focused on his/her vision without succumbing to distractions, then $\mathrm{s}$ /he may reap rewards. Frequently, in their sermons pastors urge their flock to have great ambitions: if one aims low God will grant small blessings; if one aims high, God will grant great blessings. This rhetoric shows the influence of the Pentecostal prosperity gospel within the Guinean Evangelical world, albeit in a mitigated version. According to this global doctrine, widespread in Africa since the 1990s, material wealth and well-being are considered as blessings from God, as well as signs of divine grace (Corten and Marshall-Fratani 2001; Marshall 2009; Cole 2010). Prosperity is presented as being given to those who live exemplary Christian lives, and use material gains according to Jesus's rules. Moreover, besides being a sign of God's grace and personal salvation, individual success combined with righteousness and honesty contributes to the expansion of God's plans. Since it offers an example to sinners, it 'makes a difference' and shows the glory of God to the world. While being quite widespread, the prosperity gospel has not been hegemonic, until now, among Evangelical believers in Guinea-Bissau, as far as other discourses about future and well-being are simultaneously circulating in this context. 


\section{Vison di nha terra (vision of my country)}

Besides the already mentioned connotation, the notion of vision has a second meaning, which refers to the idea of a higher Common Good. Although some authors have stressed the individualistic side of Pentecostalism (Comaroff and Comaroff 2000; Comaroff and Comaroff 2004) - at least in its more recent wave of success - in Guinean Evangelical circles the future horizon is not necessarily limited to the believer's personal life. Actually, as Pastor Quiletch emphasized, one may either have a vison about one's life, one's church, or one's nation. Indeed, the well-being and the progress of Guinea-Bissau were topics that recurred frequently both in sermons and personal conversations throughout my fieldwork.

In contrast with widespread discourses of hopelessness, related to famine, disease and distrust of a selfish and corrupt ruling class, many Evangelical believers reiterate narratives describing churches as agents of hope in Guinea-Bissau. Frequently, these narratives reproduce in their own fashion the rhetoric of progress and development expressed by NGOs and international institutions, as in the words of Pastor Dionísio Rodrigues, a Guinean missionary working in the East of the country:

In the rainy season, it is almost time of famine in tabancas (villages) [...]. And when election time comes, they give a bag of rice to each person. People are happy and vote, and the next day they still die. There's so much despair among the people...

I've taken [sick] children on the road from Sintchambotche to Gabu, the road was so bad, we could not reach Gabu quickly, and children died in our car. It is painful, you make so many efforts to save a life, and then they die just the same... You go back and the mother says: 'Djtu ka tene' (no way, it's God's will) [...]. These people face so many problems that now they accept the situation, and everything that happens they say: 'It's the will of God' $[\ldots]$.

But I believe that this is just a hard time that we are living in Guinea, all this will pass. Guinea will emerge, we will have good days, our story will not be the one that we are experiencing now, peace will return. We will find people who love this land, who love this country, and who are really interested in struggling to stabilize this country [...]. I believe in this, that is why I am still fighting with all my force as part of my religious faith; I strive for the development of my people... For me the Gospel is a God's instrument to effect change [...]. I saw how the Word of God transformed me, I feel responsible for sharing it, knowing that only the Word of God will change our minds, and enable us to change our society. When this society experiences pure Gospel, people will change [...]. It is very sad our situation, but as they say, hope is the last thing to die, so we have hope in Guinea-Bissau [...]. We do not want this cyclical upheaval that we have been having. I never gave up my faith in Guinea-Bissau; I never thought that this country will sink, as many people say. I believe that one day this nation will emerge, not even in my generation, but my children will feel the sweetness of Guinea. That's why I am working hard, to see this dream to come true. 
Such dreams of a better future have a strong political value, being in line with the political agenda of Evangelical Guinean leaders, who are actively engaged in the utopian project to transform the state through evangelization. Their program does not envision a revolution or a radical change within the actual political system, but rather foresees the redemption of society and the state through the spreading of the Gospel. To the extent that many believers view the current state of affairs in Guinea-Bissau as a moral crisis, the conversion of public officials appears as the only effective way to moralize the state. This is the firm belief of Pastor Felix da Costa, who is doing mission work among the armed forces:

When a person comes into contact with the Word of God, this person is transformed. Thus I started thinking: surely if the militaries here in Guinea-Bissau came into contact with the Gospel, they could be transformed [...]. So I began to go to the barracks [...]. Because I believe that a man who knows God is a different man. In his behaviour, he is a man who ponders before acting, before doing anything, he remembers to be a man of God, he remembers he has to account for what he does, and then the fear of God comes [...].

Here people fear the military. The militaries, in other words, are above the law. But the man who fears God knows that he may be above the law of men, but he has the law of God who is over him, you like it or not you are under the law of God and you will be responsible, as the Bible said [...]. This is why I believe that [...] if they [the Government] facilitate the evangelistic work in the barracks, many militaries will become changed, and we will see men accessible to society.

Felix's words reflect a will of individual and collective redemption, in which individual conversion opens the space for the political salvation of the nation. In this sense, conversion is a means to create the 'ideal citizen' (Marshall 2009) able to 'be the light of the world', as pastors and believers are used to say, both in spiritual and in socio-political sphere. Furthermore, this totalizing plan to redeem the nation is a politics of hope rather than a politics of desire, insofar as it considers human agency insufficient to attain collective life, depending instead on God's action for its fulfilment (Crapanzano 2003).

Being perceived as an answer to a widespread sense of moral crisis in post-Cold war GuineaBissau, the Evangelical political agenda is also an effort to create a Christian 'moral community' (Karlström 2004) grounded on social solidarity, observance of the law of God, as well as ideas of progress, development and modernity. However, insofar as it works through religious affiliation, it tends to promote exclusive rather than inclusive bonds and commitments. Hence, by rejecting the religious 'other' in a country that is marked by a high degree of religious plurality, such project reveals an inherent ambivalence, and a difficulty in creating the basis for a political community 'on this Earth'. Therefore, although Evangelicals may see their programme as having a great world- 
transforming potential, they are fostering what can be deemed an 'anti-political politics' (Piot 2010) or a 'negative political theology' (Marshall 2009) that is not without contradictions.

\section{From orphans of modernity to children of God}

As in other African countries, in contemporary Guinea-Bissau religious organizations seem to have taken over the social and bio-political fields, filling the gap left by a state that was forced by neoliberal reforms to withdraw from the social sphere (Piot 2010). Since the 1990s, Islamic and Christian associations, financed by foreign contributions and members' donations, are replacing the state as providers of social services, including education, health and development projects. Further, religious organizations are becoming proxies of the post-colonial state in another important sense. Indeed, the secular versions of modernity promoted by the nation-state are losing strength and credibility in citizens' eyes. As a matter of fact, under the combined effect of economic crisis, institutional collapse, and programmes of structural adjustment, public authorities appear to no longer be able to implement effective development programmes on a secular basis. By contrast, in offering social services and basic infrastructure, religious movements are also reviving the hope in the world to come, by presenting themselves as more reliable agents of change and creating new visions of modernity. In so doing, they foster a sense of possibility that appeared lost after the demise of the nationalist dream.

The notion of modernity as an analytical tool has been recently called into question. Critics focused especially on modernization theory, for its tendency to view 'modern society' as a homogeneous package of correlated traits, bringing together phenomena as disparate as industrial economy, modern transportation and communications, political democracy, nuclear families and secularization of world views (Ferguson 2006). To overcome the homogenizing, Eurocentric, and evolutionary biases underlying the idea of modernity as an objective 'social condition' (Knauft 2002), several anthropologists suggested that modernity should be conceived in the plural. Their ethnographically grounded analyses emphasized the elements of contingency and variability inherent in this notion, understanding it as a process of bricolage and creative invention, combining elements of 'Western modernity' with local components (Comaroff and Comaroff 1993; Piot 1999; Eisenstadt 2000). Despite the merits of its critical analysis, the 'alternative modernities' paradigm brings to light the pitfalls of modernity as an analytical concept. Indeed, when dislodged from its socio-evolutionist bias, modernity seems to 'melt into air' (Comaroff and Comaroff 1993:xii; Karlström 2004:597). 
Instead of using modernity as an analytical notion, recent works proposed another approach to the term, understanding modernity as a field of popular discourses and an 'ideology of aspiration' (Knauft 2002:33). Firstly, modernity appeared in Europe in the eighteenth century as a distinctive 'mode of temporality' (Knauft 2002), conveying the idea of 'a collective temporal trajectory from an inferior past to a qualitatively different and superior future' (Karlström 2004:597). Later, although it has gradually become a worldwide hegemonic ideology, the idea of modernity as 'the arrow of time' has been locally appropriated, reinterpreted and contested according to local and historical circumstances. As pointed out by James Ferguson (2006), in the context of African decolonization the modernization discourse was a widespread narrative of the post-independence elites, claiming that the emerging nations would have advanced, sooner or later, towards a 'modern' way of life. Today, as the nationalist narrative of development has lost its popularity, African modernity has become 'a local tongue' (Ferguson 1999) to speak about the widespread claims of membership in a wider society, in a context of extreme marginalization in a global economy. In this sense, modernity appears today less as a 'telos' in a temporalized historical sequence, than as a global 'status' and a political-economic condition, the condition of being 'first class' (Ferguson 2006:187). In other words, in contemporary Africa, modernity has shift from a category of time to a category of space, reflecting the common desire to move from a marginal place to reach the 'modern' world. In the following pages, I will focus on this second approach, understanding modernity as a distinctive and variable discourse of hope and aspiration rather than analytical tool.

In the case of Guinea-Bissau, the failure of the secular promises of modernity goes back to the deterioration of the nationalist dream. In the 1960s and 1970s, under the leadership of the national hero Amílcar Cabral and the PAIGC party, the anti-colonial movement conveyed a persuasive narrative of social and cultural regeneration, capable of motivating colonial subjects and drawing them into the nationalist project. Indeed, although the Guinean idea of nation was essentially a creole project (Trajano Filho 2010), it was through popular consent and the crucial participation of peasant warriors that nationalists were able to win the colonial war. The utopian aspect of the Guinean national movement is evident in Cabral's writings, as well as in PAIGC's efforts to build a new society in the liberated areas during the liberation war. Since the mid-1960s, PAIGC started to lay the foundations for the future society and nation-state by establishing a political and administrative organization, implementing economic policies and creating a germinal welfare state in the areas that were under their control during the war (Chabal 1983). This social and political endeavour was based on Cabral's pragmatist as well humanist assumption that people's 
welfare constituted the main way in which PAIGC could gain villagers' support, as well as legitimacy for political action. As Cabral declared in a famous text,

You shall always remember that people are not fighting for ideas, or for what is in man's mind. People fight and accept the sacrifices demanded by the struggle in order to gain material advantages, to live better and in peace, to benefit from progress and for the better future of their children. National liberation, the struggle against colonialism, the construction of peace, progress and independence are hollow words devoid of any significance unless they can be translated into a real improvement of living conditions (Cabral 1974:46) ${ }^{9}$.

These words reflect a key aspect of Cabral's leadership, that is, 'his ability to combine political effectiveness with a high degree of adherence to human decency as a principle of political action' (Chabal 1983:154). Especially, whereas Portuguese rulers had invested very little in health infrastructure, delegating 'indigenous education' to the Catholic Church (Koudawo 2001), PAIGC's social policies in liberated areas were focused on health and education. As a matter of fact, despite its limited financial resources, in the early 1970s PAIGC established a basic system of health dispensaries and primary schools across the areas under its control. These actions were consistent with Cabral's idea that schooling was a crucial means of creating political consciousness among Guinean villagers, as well as for the education of the 'homem novo' (new man), the subject-citizen of the future nation (Chabal 1983).

Investment in welfare continued after Cabral's murder and during the first years following independence, as the new state was supported through international cooperation, both from Western Europe and the Soviet bloc. Yet, since the late 1980s the process of liberalization led to a rapid reversal of the slight progress achieved in welfare state provision. While I was roaming across Bissau with my Guinean friends in search of medicines, medical tests or health care, they used to remember with nostalgia the early years of independence, when Guinea-Bissau was called the 'Switzerland of Africa', and people came from all over West Africa to be treated at the Simão Mendes hospital in Bissau. Although these may be idealized memories, they clearly reflect the common perception of a marked contrast between the immediate post-colonial past and the postCold War present, with regards to public health. More generally, they hint at a time of social aspirations and political commitment, a time when a Guinean path towards modernity and development still seemed possible and within reach. Indeed, the murder of the national hero and the events that followed, including Nino Vieira's military regime and neo-liberal reforms, led to the failure of the nationalist dream in Guinea-Bissau, as happened across much of Africa.

While these collective dreams of a better future appear to have vanished for most people, they seem to have re-emerged in a different guise amongst Evangelical Guineans. In the face of 
poverty, violence, despair and collapse of the state, Evangelical churches - together with NGOs and other religious organizations - are among the few institutions which provide people with support, solidarity, social networks, and hope in the world to come. In this sense, the reproduction of Cabral's words next to the image of an African island of Utopia on Casa Emmanuel's wall seems to depict Evangelical churches and organizations as the very heirs of Amílcar Cabral, insofar as they are revitalizing the utopian impulse of those who fought for independence. As a young Evangelical journalist told me, 'I see Guinea-Bissau within ten years as a stable country, a country moving towards that development which was dreamed forty years ago, when the liberation struggle was fought'.

While at first sight nationalists' ideals and evangelicals' hope may appear at odds with each other, they reveal several affinities at a closer examination. Significantly, one of the central notion in the texts of Amílcar Cabral is the concept of 'homem novo' (new man), the citizen of the future nation emerging from the liberation war. Cabral was referring to a notion which was central to the Soviet experiment, implicating the transformation of the individual human, body and soul, in order to remake society through the creation of a new type of man. The Stalinist version of the new man, while having its origins in Russian political thought and cultural history, was quite widespread in many socialist countries. And yet, despite its centrality in socialist ideology and its circulation throughout the socialist world, this concept has a striking resonance with the Christian motif of the new man, expressed for the first time by Paul of Tarsus. In his letters, Paul described the special transformation that a person undergoes, when s/he encounters Christ. In Paul's view, the relation with the Messiah revokes any mundane condition and totally renovates the self, while any former identity loses its value:

You were taught, with regard to your former way of life, to put off your old self, which is being corrupted by its deceitful desires; to be made new in the attitude of your minds; and to put on the new self, created to be like God in true righteousness and holiness [Eph. 4:22-24].

The parallel between the nationalist and the Christian notion of new man may go even further. Interestingly, Cabral's ideas of progress, modernity and development have many points in common with the current narratives of Evangelical Guineans. The political project of the PAIGC's leader to build a new, just and progressive society had manifold dimensions, including the political, economic, military and cultural domains as well as the individual sphere. In this totalising program, Cabral placed special emphasis on the notion of 'cultural resistance', which consisted in 'defeating the colonial culture and the negative aspects of our own culture in our spirit', and 'creating a new culture based on our traditions, but respecting all that the world has achieved today to serve the 
man' (Cabral 1974:190). Hence, far from rejecting entirely the colonial culture, Cabral encouraged his comrades to 'leave in our head that aspect of human, scientific culture that the tuga [the Portuguese] brought to our land by chance, and entered our head too' (Cabral 1974:188). Concurrently, he harshly attacked those indigenous mentalities that he judged as reactionary and superstitious, including beliefs in spirits and witchcraft:

\footnotetext{
The armed liberation struggle requires $[\ldots]$ the progressive demolishment of the remnants of tribal mentality, the refusal of rules and social and religious taboos which are contrary to the development of the struggle (gerontocracy, nepotism, social inferiority of women, rites and practices which are incompatible with the rational and national nature of the struggle, etc.) and it operates many other profound changes in people's lives. The armed liberation struggle, therefore, implies a real forced march on the path of cultural progress (Cabral 1974:117).
}

While Cabral's jettisoning of 'ignorance' and 'superstition' is consistent with Marxist rationalism, it is concurrently resonant with the Evangelical demonization of tradition. As a matter of fact, like elsewhere in Africa, since their presence in Guinea-Bissau Protestant missions and churches have enhanced a process of demonization of local religion, whereby local spirits and deities are integrated into the Evangelical discourse as 'Christian' demons. At the same time, 'tradition' has been represented as a matter of the 'past', while new converts have been urged to 'make a 'complete break with the past' in order to start a new life and achieve salvation (Meyer 1998). In this sense, both nationalist and Protestant discourses are stressing the necessity of leaving behind those 'remnants of tribal mentality' which are held to be in contrast with 'the development of the struggle', on the one hand, and the principles of Christianity, on the other, in order to speeding up the pace towards 'cultural progress' and personal salvation.

Far from being limited to the domain of ideas, the utopian drive shared by former nationalists and actual Evangelicals translates in the sphere of action. Starting from the assumption that 'utopia, more than a frame of mind that engages in ideals, actually works in practice', Ruy Blanes and others (2016) proposed to use the concept of 'microtopias' to analyse the 'creativity of social life'. While the notion of 'microtopias' was originally created by Nicolas Bourriaud (Bourriaud 1998:13) with reference to art practices as collective, inter-relational and contextualised endeavours, the authors suggested to extend its meaning to encompass not only processes of artistic production, but also local cooperation, collective music making, urban engineering, political organisations and open source movements. Their reflections have the merit of showing how the concept of utopia is not limited within the sphere of the ideal, imaginary and even illusory, but may also include those instances of 'utopias in practice', in which a 'constituent imagination' (Shukaitis, 
Graeber, and Biddle 2007) takes form, able to transform imagination into materiality, and potentiality into actuality. From this perspective, Casa Emmanuel's childcare 'exemplary project' can be described as an example of microtopia. In contrast with the decaying infrastructure, the nonfunctioning institutions and the lack of social services which are a commonplace for Bissau's inhabitants, workers and users represent this centre as an island of progress and good practices in a sea of neglect. Moreover, the reference to Amílcar Cabral on its walls is not accidental. By providing indigenous people with literacy and health in the liberated areas during the liberation war, nationalists were putting utopia into action, starting a process of social creativity and laying the foundations for the future nation. Likewise - though under different ethics and worldviews - by supplying citizens with social and health care, Evangelical churches and organizations are opening the space for a future Christian society on this earth. Put in other words, by opening spaces where new relations, practices and dispositions are actually produced, both early nationalists and contemporary Evangelicals are creating ‘eutopian’ worlds, that is, 'places of happiness and order that are not 'no-places' or utopias - that is, not a phantasmatic impossibility but a realizable ideal' (Karlström 2004:596).

On the basis of these affinities, nationalist and Evangelical dreams of a better future may be understood as two distinct expressions of the human drive towards a 'good new' (Bloch 1986), regardless of their specific contents. In The Principle of Hope, Ernst Bloch (1986) regarded hope as a basic principle of the human being, emerging under various guises throughout the course of history. In his view, a tension towards the 'good new' has been continuously experienced by the human kind. Throughout history, and in all cultures, people have produced various kinds of utopias, ranging from daydreams to the fantasies contained in fairy tales, film and theatre, to utopias designed in architecture, painting or literature, to religious utopias, up to the 'concrete utopia' represented by socialism. While Bloch placed Marxism at the highest point of human drive towards the future, by virtue of its capacity to combine hope with planning and reason in order to change the world economically and dialectically, concurrently he connected socialism with early forms of utopian aspiration, including Christianity. According to Bloch, the authentic core of Christianity is genuinely utopian, as the message contained within Jesus Christ's teaching foreshadowed the end of human suffering, promoting a utopia of eschatological fraternity through the example of his life. More than this, the memory of Jesus after his death generated a 'second eschatology', establishing unprecedented dimensions of hope: he would return to fulfil the kingdom of man, appointing the Holy Ghost as his representative until his return, and forecasting 'the apocalyptic transformation of the world into something as yet completely inexistent' (Bloch 1986:1274). On this basis, Bloch described Christian 'advent morality' as an anticipation of Marxism after its own fashion, one that 
prefigures socialist promotion of humanity and the drive towards the future while lacking Marxist knowledge and propensity to change the actual state of things. In his view, although the Christian promise of a better world can be held as empty and deceptive, insofar the higher good is postponed until the afterlife or the End of Time, both Christianity and Marxism are moved by the principle of hope, in which forward dreams are motors of action and change.

In the previous pages I argued that, in contemporary Guinea-Bissau, Evangelical churches are promoting a new politics of hope that translates Cabral's legacy in their own terms. And yet, a fundamental difference is worth to be noted, reflecting the contrast between the revolutionary spirit of the 1960s and 1970s and the cosmopolitan spirit of post-Cold War times. The Guinean nationalist project was in line with the modernization narrative that served as 'a blueprint for the 'nation-building' and 'economic-development' programs' of the African post-independence elites (Ferguson 2006:182). By contrast, in contemporary Africa, due to a rising contrast between inclusion and exclusion and a widespread feeling of marginality, modernity has ceased to be associated with the narrative of national development and progress. Instead, popular discourses about modernity in Africa are currently reflecting a widespread claim of membership in a wider society. Under this conjuncture, people are seeking new strategies to secure their own futures. Whereas at the time of decolonization the future took the form of societal progress and national development, today it is increasingly associated with individual spatial mobility. According to Ferguson, we are assisting to a shift from 'progress' to 'egress', in a new political space that is not 'utopian' but 'aspirational' (Ferguson 2006: 191).

The discontinuity between nationalist and Evangelical discourses about the future is evident when we examine their divergent judgments on migration. Consistently with his nationalist vision, Cabral was firmly against emigration. In his speeches, he exhorted his comrades to 'reinforce surveillance at all borders, to prevent the outflow of arms which are useful to our economy' (Cabral 1974:46). In Cabral's view, emigration was a loss for the country's economy, and reflected a lack of sense of responsibility for the common good of the future nation. By contrast, today Evangelical leaders see the mobility of people to and from Guinea-Bissau as a resource for the country. Firstly, the circulation of foreign missionaries - especially from Brazil - bringing spiritual and material aid to the local population is commonly held as a 'blessing' and an added value for the country. Secondly, migration of young people is viewed as a crucial asset for the nation. According to a recurrent discourse, thanks to Christian youth who are going to study or work in other countries with the idea of contributing to the progress of their homeland, Guinea-Bissau will become more developed and more connected to the world, and of course more in line with the plans of God. 
In a context in which the decay of the Guinean nationalist dream resulted in widespread pessimism and disillusion, reflected in a general eagerness to sai fora, Guinean Evangelical believers are not immune from the common longing to escape. And yet, I do not believe that, within the Evangelical Guinean world, the utopian drive towards the common good has completely given way to personal aspirations and individual wishes for mobility. On the contrary, I am convinced that the early utopian impulse is now projected onto a post-national horizon, fostering new belongings and allegiances outside of the logic of the nation-state. Within this framework of multiple belongings, continuously swinging between global and local, one can be connected with the universal community in Christ while living in Bissau, struggling for the development of his/her country and simultaneously planning and support migration projects. From this perspective, Evangelical Guinean churches are fostering a conceptualization of modernity that seems less associated with an individualistic desire to leave a marginal place to join a first-class society, and more with a wish to 'be connected' and keep multiple memberships in a global world. Moreover, this vocation for connectivity can account for the recent success of Protestantism - and more generally of universal religions - in Guinea-Bissau. By combining evangelization with health and social services, Evangelical organizations are often considered by local people as a development resource as well as a possibility of belonging to global networks, 'a point of entry into the modern and the global' (Piot 2010:162). As observed by Ramon Sarró and Miguel De Barros (forthcoming), in contemporary Guinea-Bissau global religions 'are seen today as local mechanisms to reach modernity and to be connected to a wider world', on the assumption that 'religion brings connection'.

\section{Conclusion}

In dialogue with the recent anthropological scholarship on future, hope and aspirations, in this article I analysed the peculiar ways in which Evangelical believers in Guinea-Bissau are engaged in imagining, thinking and producing their future. In this context, I argued, specific ideas about time emerged from the encounter between particular historical and cultural circumstances, on the one hand, and peculiar ideas about future and hope that have their origin in Christian traditions, on the other. Following Jennifer Cole, I described such emerging visions of time as a set of 'multiple temporalities' (Cole 2010), resulting from a synergy between local views, Christian categories, as well as specific historical circumstances.

Among Evangelical Guineans, I suggested, the idea of future is shifting between three different temporalities, used by individuals according to variable circumstances and different 
communicative contexts. The first horizon is directed to the distant future, being associated with the End of Time narrative, a globally widespread Evangelical orientation toward time focused on the 'expectant waiting' (Guyer 2007) of Messiah. The second and the third perspectives, both contained within the notion of vison, are oriented towards the near future. Based on the Christian principle of individual salvation, the concept of vison has a double meaning: on the one hand, it refers to personal expectations and plans for one's life; on the other, it relates to collective aspirations to a Common Good. As I emphasized in the previous pages, the latter dimension has a strong political value, being in line with the Evangelical project to redeem state and society through evangelization, under the assumption that individual conversion opens the space for the political salvation of the nation.

Finally, I showed how, in contemporary Guinea-Bissau, Evangelical churches present themselves as the very heirs of Amílcar Cabral, insofar as they are revitalizing after their own fashion the utopian impulse of those who fought for independence. Like the nationalist movement in the 1960s and 1970s, the Evangelical movement is creating today new 'microtopias' or 'eutopias' that translate ideas into action, and utopia into practice. The former, by providing indigenous people with literacy and health in the liberated areas during the liberation war, started a process of social creativity that laid the foundations for the upcoming nation. The latter, by supplying citizens with social and health care, as well as spiritual salvation, is opening the space for a future Christian society on this Earth. These two projects of social regeneration may be understood as two distinct expressions of the human drive towards a 'good new', moved by the 'principle of hope' (Bloch 1986). Nonetheless, they are channelling contrasting views about modernity: for nationalists, modernity was a telos to be attained by the emergent nation-state after independence; for presentday Evangelicals, modernity is a way of life that people can achieve through global connections. Therefore, while in contemporary Guinea-Bissau the nationalist developmental narrative is commonly held as a broken promise, the new version of modernity as connectivity conveyed by Evangelical churches appears as increasingly persuasive and in line with common aspirations. By

offering social services, basic infrastructure, global connections and hope in the world to come, they foster a sense of possibility that appeared buried under the debris of the post-colonial state.

\section{Bibliography}

Agamben, Giorgio. 1998. Homo Sacer: Sovereign Power and Bare Life. Stanford University Press. Stanford: Stanford University Press. 
Agamben, Giorgio. 2005. The Time That Remains: A Commentary on the Letter to the Romans. Stanford: Stanford University Press.

Appadurai, Arjun. 2013. The Future as Cultural Fact: Essays on the Global Condition. London-New York: Verso Books.

Bayart, Jean-François, Stephen Ellis, Béatrice Hibou, and International African Institute. 1999. The criminalization of the state in Africa. [London]; Bloomington: International African Institute in association with J. Currey, Oxford: Indiana University Press.

Blanes, Ruy Llera, Alex Flynn, Maïté Maskens and Jonas Tinius. 2016. 'Micro-utopias: anthropological perspectives on art, relationality, and creativity'. Cadernos de Arte e Antropologia 5.1, 5-20.

Bloch, Ernst. 1986. The Principle of Hope. Oxford: Basil Blackwell.

Bordonaro, Lorenzo. 2009. 'Sai Fora: Youth, Disconnectedness and Aspiration to Mobility in the Bijagó Islands (Guinea-Bissau)’. Etnográfica 13.1, 125-144.

Bourriaud, Nicolas. 1998. Esthétique Relationnelle. Dijon: Les Presses du Réel.

Brooks, George E. 1993. Landlords and Strangers: Ecology, Society, and Trade in Western Africa, 1000-1630. San Francisco: Westview Press.

Brooks, George E. 2003. Eurafricans in Western Africa: Commerce, Social Status, Gender, and Religious Observance from the Sixteenth to the Eighteenth Century. Athens: Ohio University Press and Oxford: James Currey.

Cabral, Amílcar. 1974. PAIGC: unidade e luta. Lisboa: Nova Aurora.

Chabal, Patrick. 1983. Amílcar Cabral: Revolutionary Leadership and People's War. Cambridge: Cambridge University Press.

Cole, Jennifer. 2010. Sex and Salvation: Imagining the Future in Madagascar. Chicago: University of Chicago Press.

Comaroff, Jean, and John L. Comaroff (eds.). 1993. Modernity and Its Malcontents. Chicago: University of Chicago Press.

Comaroff, Jean, and John L. Comaroff .1999. 'Occult Economies and the Violence of Abstraction: Notes from the South African Postcolony'. American Ethnologist 26.2, 279-303.

Comaroff, Jean, and John L. Comaroff. 2000. 'Millennial Capitalism: First Thoughts on a Second Coming'. Public Culture 12.2, 291-343.

Comaroff, Jean, and John L. Comaroff. 2004. 'Notes on Afromodernity and the Neo World Order: An Afterword'. In Weiss, Brad (ed.), Producing African Futures: Ritual and Reproduction in a Neoliberal Age. Leiden: Brill. 
Corten, André, and Ruth Marshall-Fratani (eds.). 2001. Between Babel and Pentecost:

Transnational Pentecostalism in Africa and Latin America. London: Hurst \& Co.

Crapanzano, Vincent. 2001. Serving the Word: Literalism in America from the Pulpit to the Bench. New York: New Press.

Crapanzano, Vincent. 2003. 'Reflections on Hope as a Category of Social and Psychological Analysis'. Cultural Anthropology 18.1, 3-32.

Duarte Silva, António E. 2010. Invenção e Construção da Guiné-Bissau (Administração Colonial/Nacionalismo/Constitucionalismo). Coimbra: Edições Almedina.

Eisenstadt, Shmuel Noah. 2000. Multiple Modernities. New Brunswick: Transaction Publishers.

Entralgo, Pedro Laín. 1957. La espera y la esperanza historia y teoría del esperar humano. Madrid: Revista de Occidente.

Ferguson, James. 1999. Expectations of Modernity: Myths and Meanings of Urban Life on the Zambian Copperbelt. Berkeley: University of California Press.

Ferguson, James. 2006. Global Shadows: Africa in the Neoliberal World Order. Durham: Duke University Press.

Gaillard, Gérald. 2002. 'Islam et Vie Politique En Guiné-Bissau Contemporaine'. In L'Afrique Politique. Paris: Kartala et Cean.

Guyer, Jane I. 2007. 'Prophecy and the near Future: Thoughts on Macroeconomic, Evangelical, and Punctuated Time'. American Ethnologist 34.3, 409-421.

Harding, Susan Friend. 2001.The Book of Jerry Falwell: Fundamentalist Language and Politics. Princeton: Princeton University Press.

Karlström, Mikael. 2004. 'Modernity and Its Aspirants: Moral Community and Developmental Eutopianism in Buganda'. Current Anthropology 45.5, 595-619.

Knauft, Bruce M. (ed). 2002. Critically Modern: Alternatives, Alterities, Anthropologies. Bloomington: Indiana University Press.

Knörr, Jacqueline, and Wilson Trajano Filho (eds.). 2010. The Powerful Presence of the Past: Integration and Conflict Along the Upper Guinea Coast. Leiden: Brill.

Koudawo, Fafali. 2001. Cabo-Verde E Guiné- Bissau: Da Democracia Revolucionária à Democracia Liberal. Bissau: Instituto Nacional de Estudo e Pesquisa (Colecção Kacu Martel, volume14).

Marshall, Ruth. 2009. Political Spiritualities: The Pentecostal Revolution in Nigeria. Chicago: University of Chicago Press.

Meyer, Birgit. 1998. 'Make a Complete Break with the Past. Memory and Post-Colonial Modernity in Ghanaian Pentecostalist Discourse'. Journal of Religion in Africa 28.3, 316-349. 
Miyazaki, Hirokazu. 2005. 'From Sugar Cane to 'Swords': Hope and the Extensibility of the Gift in Fiji'. Journal of the Royal Anthropological Institute 11.2, 277-295.

Miyazaki, Hirokazu. 2006. 'Economy of Dreams: Hope in Global Capitalism and Its Critiques'. Cultural Anthropology 21.2, 147-172.

Moore, Henrietta L. 2011. Still Life. Hopes, Desires and Satisfactions. Cambridge: Polity Press.

Piot, Charles. 1999. Remotely Global: Village Modernity in West Africa. Chicago: University of Chicago Press.

Piot, Charles. 2010. Nostalgia for the Future West Africa after the Cold War. Chicago: University of Chicago Press.

Robbins, Joel. 2004. Becoming Sinners: Christianity and Moral Torment in a Papua New Guinea Society. Berkeley: University of California Press.

Rodney, Walter. 1970. A History of the Upper Guinea Coast 1541-1800. Oxford: Clarendon Press.

Sarró, Ramon, and Miguel de Barros. Forthcoming. 'History, Mixture, Modernity: Religious Pluralism in Guinea-Bissau Today'.

Shukaitis, Stevphen, David Graeber, and Erika Biddle (eds.). 2007. Constituent Imagination: Militant Investigations, Collective Theorization. Oakland: AK Press.

Trajano Filho, Wilson. 1993. 'Rumores: Uma Narrativa Da Nação’. Série Antropologia 143.

Trajano Filho, Wilson. 2008. 'O Precário Equilíbrio Entre Improvisação E Regras: Reflexões Sobre a Cultura Política Da Guiné-Bissau’. Revista de Antropologia, 233-266.

Trajano Filho, Wilson. 2010. 'The Creole Idea of Nation and Its Predicaments: The Case of GuineaBissau'. In Knörr, Jacqueline, and Wilson Trajano Filho (eds.), The Powerful Presence of the Past: Integration and Conflict Along the Upper Guinea Coast. Leiden: Brill, 157-184.

Vigh, Henrik, 2010. 'Youth Mobilisation as Social Navigation. Reflections on the Concept of Dubriagem'. Cadernos de Estudos Africanos 18.19, 139-164.

Weiss, Brad. 2004a. 'Introduction: Contentious Futures: Past and Present'. In Producing African Futures: Ritual and Reproduction in a Neoliberal Age. Leiden: Brill.

Weiss, Brad (ed.). 2004b. Producing African Futures: Ritual and Reproduction in a Neoliberal Age. Leiden: Brill. 


\section{Notes}

\footnotetext{
${ }^{1}$ In this article, I use the term 'Evangelical' to include all the recent streams of spiritual renewal that have their origins in Protestant Reformation, such as Methodism, Pentecostalism and part of Baptism. The use of this term is deliberately inclusive, doing justice to the heterogeneity of the Guinean Evangelical movement. As a matter of fact, despite the great spread of the Pentecostal 'new wave' in Africa (Corten and Marshall-Fratani 2001, among others), in Guinean Evangelical denominations 'conservative' doctrines, practices and styles transmitted by early Protestant missionaries coexist with Pentecostal and neo-Pentecostal models, conveyed by new churches that arrived in Guinea-Bissau in the last two decades. ${ }^{2}$ The PAIGC (Partido Africano da Independência da Guiné e Cabo Verde, African Party for the Independence of Guinea and Cape Verde) was the organization which led the independence war against Portugal (1963-1974). Its leader, Amílcar Cabral, was assassinated in Conakry by two members of his own party on 20 January 1973, before the proclamation of independence. The instigators of the murder are still unknown.

${ }^{3}$ All inteviews were realized in Portuguese, while sermons were in Kriol.

${ }^{4}$ The prosperity doctrine has its origins in the Word of Faith movement (also called 'health-and-wealth' or 'name it and claim it') that spread in the United States since the 1970s. The preachers of the Word Faith, which had a strong influence on the Pentecostal 'new wave' in Latin America, Africa and Asia since the early 1980s, claimed that God provides the faithful with spiritual as well as material blessings. These forms of wordly wellbeing - which include money, but also physical health and personal success - could be evoked simply by naming and asking them in the name of Jesus (Marshall 2009).

${ }_{6}^{5}$ All quotes in Portuguese were translated into English by the author.

${ }^{6}$ The military uprising was led by General Ansumane Mané, former Chief of the Armed Forces, fired by Nino Vieira for alleged arms trafficking. While the military junta was supported by most of the army and by many veterans of the colonial war, president Nino Vieira could only rely on his closest followers and a small number of soldiers. Without the support of the military, Nino Vieira was forced to seek help from his foreign allies. As a result, troops from Senegal and GuineaConakry arrived in Bissau to support the faction of the president, being experienced by the local population as a foreign occupation force.

${ }^{7}$ The early Protestant missionaries belonged to the Worldwide Evangelization Crusade (WEC), an interdenominational Christian organization initially based in the United Kingdom, and originally influenced by holiness doctrines.

${ }^{8}$ The same dynamic occurred within the Islamic field: many large mosques of Bissau were built between 1986 and 1991 , during the process of economic and political liberalization, with funds from Saudi Arabia, Kuwait and Libya. As well, Islamic associations proliferated in the same period (Gaillard 2002).

${ }^{9}$ Cited and translated in Chabal (1983:105).
} 